\begin{tabular}{|c|c|}
\hline \multirow{3}{*}{ 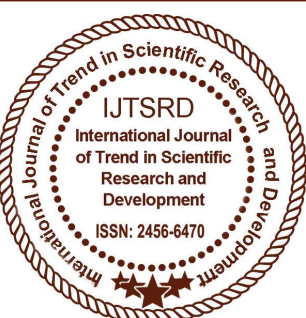 } & $\begin{array}{l}\text { International Journal of Trend in Scientific } \\
\text { Research and Development (IJTSRD) }\end{array}$ \\
\hline & International 0 \\
\hline & ISSN No: 2456 - 6470 | www.ijtsrd.com | Volume - 2 | Issue - 5 \\
\hline
\end{tabular}

\title{
Preliminary Studies on Mean Levels of Vehicular Emissions at Sections of Owerri Road Nigeria
}

\author{
Dr. Umunnakwe Johnbosco Emeka ${ }^{1}$, Dr. Aharanwa Bibian Chimezie ${ }^{2}$ \\ ${ }^{1}$ Department of Environmental Technology, ${ }^{2}$ Department of Polymer and Textile Engineering \\ Federal University of Technology, Owerri Imo State, Nigeria
}

\section{ABSTRACT}

The study, investigated the vehicular emissions on the ambient air quality of sections of Owerri municipal road by measuring the mean concentrations of $\mathrm{CO}$, $\mathrm{NO} 2, \mathrm{SO} 2, \mathrm{VOCs}, \mathrm{NH} 3$ and suspended particulate matter (PM7, PM10 and TSP) arising mainly from the activities of motor vehicles in the month of October, 2017. The sampled stations were Wetheral road, Okigwe road and Control Roundabout, which constitute one of the heaviest traffic congestion hotspots in the city. The sampling was carried out both in the morning and afternoon on four sampling stations and a control point and standard methods were adopted for field investigations. The levels of gaseous emissions from vehicular activities were sampled using a gas measuring meter of models BW Multi gas Monitor, Aeroqual Environmental gas Monitor and Aerocet 531 particle mass monitor for (H2S, CO, NH3, CH4), (NO2, SO2, VOCS) and (Suspended particulate matter ranging from PM1 PM10 and TSP) respectively. The result of the study showed that with the exception of NH3 (3.889ppm) and $\mathrm{CO}(7.944 \mathrm{ppm})$ other air pollutants $\mathrm{NO} 2$ (0.108ppm), SO2 (0.146ppm), VOCs $(0.556 \mathrm{ppm})$, PM7 $(0.088 \mathrm{mg} / \mathrm{mm} 3)$, PM10 $(0.140 \mathrm{mg} / \mathrm{mm} 3)$ and TSP $(0.216 \mathrm{mg} / \mathrm{mm} 3)$ measured exceeded the concentration values stipulated by Federal Ministry of Environment (FMEnv.), WHO (World Health Organization) and the United State Environmental Protection Agency (USEPA). This could result to adverse environmental and health implications among the inhabitants. Regular air quality monitoring for better healthy living among residents of the study area is recommended.

Keywords: Emission, Vehicular, Owerri Air Quality, Sampling

\section{INTRODUCTION}

Air Pollution occurs when the air contains substances either particles, liquids or gases in quantities that could harm the comfort or health of humans and animals, damage plants and materials (Alias et al., 2007). As many cities around the world become more congested, concerns increase over the level of urban air pollution such as our use of motor vehicles. Urban air quality is paramount on environmental issues around the world (Colvileet al., 2001) and estimate worldwide shows that nearly one billion people in urban environments are continuously being exposed to health hazards from air pollutants (Ahrens, 2003). Air pollutants from road traffic emitted from the combustion of liquid or gaseous fossil fuels can affect health in different ways and in varying degrees of severity ranging from minor irritation through serious illness, to premature death (Dickey, 2000). Although thousands of air pollutants from road traffic can be identified, the main gases in the atmosphere and their approximate percentages in dry air according to David and Frederikse, (1997) are as shown in Table 1.

Table 1: Composition of air in percent by volume at sea level at $15^{\circ} \mathrm{C}$ and 101325 pa.

\begin{tabular}{|c|c|c|}
\hline Gases & Symbol & $\begin{array}{c}\text { Percentage } \\
\text { composition in air }\end{array}$ \\
\hline Nitrogen & $\mathrm{N}$ & $78.084 \%(780840 \mathrm{ppm})$ \\
\hline Oxygen & $\mathrm{O}_{2}$ & $\begin{array}{c}20.9476 \% \\
(209476 \mathrm{ppm})\end{array}$ \\
\hline Argon & $\mathrm{Ar}$ & $0.934 \%(9340 \mathrm{ppm})$ \\
\hline Carbon(iv)oxide & $\mathrm{CO}_{2}$ & $0.0314 \%(314 \mathrm{ppm})$ \\
\hline Neon & $\mathrm{Ne}$ & $\begin{array}{c}0.001818 \% \\
(18.81 \mathrm{ppm})\end{array}$ \\
\hline Methane & $\mathrm{CH}_{4}$ & $0.0002 \%(2 \mathrm{ppm})$ \\
\hline
\end{tabular}


International Journal of Trend in Scientific Research and Development (IJTSRD) ISSN: 2456-6470

\begin{tabular}{|c|c|c|}
\hline Gases & Symbol & $\begin{array}{c}\text { Percentage } \\
\text { composition in air }\end{array}$ \\
\hline Helium & $\mathrm{He}$ & $0.000524 \%(5.24 \mathrm{ppm})$ \\
\hline Krypton & $\mathrm{Kr}$ & $0.000114 \%(1.14 \mathrm{ppm})$ \\
\hline Hydrogen & $\mathrm{H}$ & $0.00005 \%(0.5 \mathrm{ppm})$ \\
\hline Xenon & $\mathrm{Xe}$ & $\begin{array}{c}0.0000087 \% \\
(0.087 \mathrm{ppm})\end{array}$ \\
\hline Ozone & $\mathrm{O}_{3}$ & $0.000007 \%(0.07 \mathrm{ppm})$ \\
\hline $\begin{array}{c}\text { Nitrogen } \\
\text { dioxide }\end{array}$ & $\mathrm{NO}_{2}$ & $0.000002 \%(0.02 \mathrm{ppm})$ \\
\hline Iodine & $\mathrm{I}_{2}$ & $0.000001 \%(0.01 \mathrm{ppm})$ \\
\hline $\begin{array}{c}\text { Carbon } \\
\text { monoxide }\end{array}$ & $\mathrm{CO}^{\text {Trace }}$ \\
\hline Ammonia & $\mathrm{NH}_{3}$ & Trace \\
\hline
\end{tabular}

Source: David and Frederikse, (1997)

Road traffic is the dominant, if not the most important, anthropogenic source of $\mathrm{CO}$, NOx and HCin urban areas which are emitted in close proximity to human receptors, which enhances exposure levels (Fenger, 1999, Rouphailet al, 2001). The health challenges faced by road users, passers-by, residents and business operators in traffic flash points, having high concentration of vehicular traffic during some periods of the day are worrisome issues (Utang and Peterside, 2011).

Vehicular emissions are significant contributors to Ambient air Quality Index (AQI) especially in urban

areas which can contribute to high level of urban air pollution, adverse socioeconomic, environmental, health, and welfare impacts. In city centres and congested streets, traffic can be responsible for 80-90 $\%$ of these pollutants and this situation is particularly severe in cities in developing countries (White legg and Haq, 2003). Traffic congestion in Owerri increases vehicle emissions and degrades ambient air quality, and recent studies in other cities of Nigeria, have shown excess morbidity and mortality for drivers, commuters and individuals living near major roadways (Asheshi, 2012). Traffic emissions contribute about 50 to $80 \%$ of $\mathrm{NO}_{2}$ and $\mathrm{CO}$ concentration in developing countries (Fu, 2001; Goyal, 2006).Furthermore, in developing countries the super emitters contribute about $50 \%$ of harmful emissions to the entire average emission (Brunekreef, 2005).AQI is an index (Tables 2,3) for reporting daily air quality in the United States (USEPA, 2003).

\begin{tabular}{|c|c|}
\hline AQI Range & Air Quality Condition \\
\hline $0-50$ & Good \\
\hline $51-100$ & Moderate \\
\hline $101-150$ & Unhealthy for sensitive group \\
\hline $151-200$ & Unhealthy \\
\hline $201-300$ & Very unhealthy \\
\hline $301-500$ & Hazardous \\
\hline
\end{tabular}

Source: USEPA (2003)

Table 2: Interpretations of the AQI values classification USEPA (2003)

\begin{tabular}{|c|c|c|c|c|c|}
\hline Index Values & AQI Category & $\mathrm{AQI}$ Rating & $\mathbf{C O}(\mathrm{ppm})$ & $\mathbf{N O}_{2}(\mathrm{ppm})$ & $\mathrm{SO}_{2}(\mathrm{ppm})$ \\
\hline $0-50$ & Good & $\mathrm{A}$ & $0-4.4$ & $0-0.053$ & $0-0.035$ \\
\hline $51-100$ & Moderate & $\mathrm{B}$ & $4.5-9.4$ & $0.054-0.1$ & $0.036-0.075$ \\
\hline $101-150$ & Unhealthy for sensitive groups & $\mathrm{C}$ & $9.5-12.4$ & $0.101-0.36$ & $0.076-0.185$ \\
\hline $151-200$ & Unhealthy & $\mathrm{D}$ & $12.5-15.4$ & $0.361-0.64$ & $0.186-0.304$ \\
\hline $201-300$ & Very unhealthy & $\mathrm{E}$ & $15.5-30.4$ & $0.65-1.24$ & $0.305-0.604$ \\
\hline $301-500$ & Hazardous & $\mathrm{F}$ & $30.5-50.4$ & $1.25-2.04$ & $0.605-1.004$ \\
\hline
\end{tabular}

Source: USEPA (2003)

Table 3 shows the Nigerian National Ambient Air Quality approved Standards by the Federal Ministry of Environment according to Nwachukwuetal., (2012).

Table 3: Nigerian National Ambient Air Quality Standards.

\begin{tabular}{|c|c|c|}
\hline Pollutants & Averaging time & Limits \\
\hline Particulates & lhour & $250 \mathrm{ug} / \mathrm{m}^{3}$ \\
\hline Sulphur dioxide $\left(\mathrm{SO}_{2}\right)$ & $1-24$ hours & $0.01-0.1 \mathrm{ppm}$ \\
\hline Nitrogen dioxide $\left(\mathrm{NO}_{2}\right)$ & $1-24$ hours & $0.04-0.06 \mathrm{ppm}$ \\
\hline Carbon monoxide $(\mathrm{CO})$ & $1-8$ hours & $10-20 \mathrm{ppm}$ \\
\hline Hydrocarbon & 3 hours & $0.6 \mathrm{ppm}$ \\
\hline Photochemical oxidants & 1 hour & $0.06 \mathrm{ppm}$ \\
\hline
\end{tabular}


In Nigeria little reference is made on damage of pollution caused by mobile transportation sources of air pollution (Faboye, 1997; Iyoha, 2000; Magbabeola, 2001). In other studies, only casual references are made to the gravity of the problem of pollution from mobile transportation sources (World Bank, 1995; Garba and Garba, 2001).

\section{STUDY AREA}

Owerri is the capital of Imo state in Nigeria, situated in the South-eastern part of Nigeria. Owerri, the state's largest city consists of three Local Government Areas including Owerri Municipal, Owerri North and Owerri West (Fig.1). It has an estimated population of about 401,873 as of 2006 and is approximately 100 square kilometres (40sq $\mathrm{mi}$ ) in area (Wikipedia, 2016).Some major roads that transverse the city are;
Port Harcourt Road, Aba Road, Onitsha Road and Okigwe Road. Some busy roads within the city are Douglas Road, Wetheral Road, Tetlow Road and Works Road.

Owerri falls within the rain forest and produces many agricultural products, such as yam, cassava, corn, rubber and palm products. Owerri has a tropical wet climate according to the Koppen-Geiger system. Rain falls for most months of the year with a brief dry season. The Harmattan affects the city in the early periods of the dry season and it is noticeably less pronounced than in other cities in Nigeria. The mean annual temperature rangs between $26-28{ }^{\circ} \mathrm{C}$, with humidity that varies between $50.5-70.5 \%$.Owerri municipal is characterized by influx of people and high volume of vehicular flows in and out of the area.
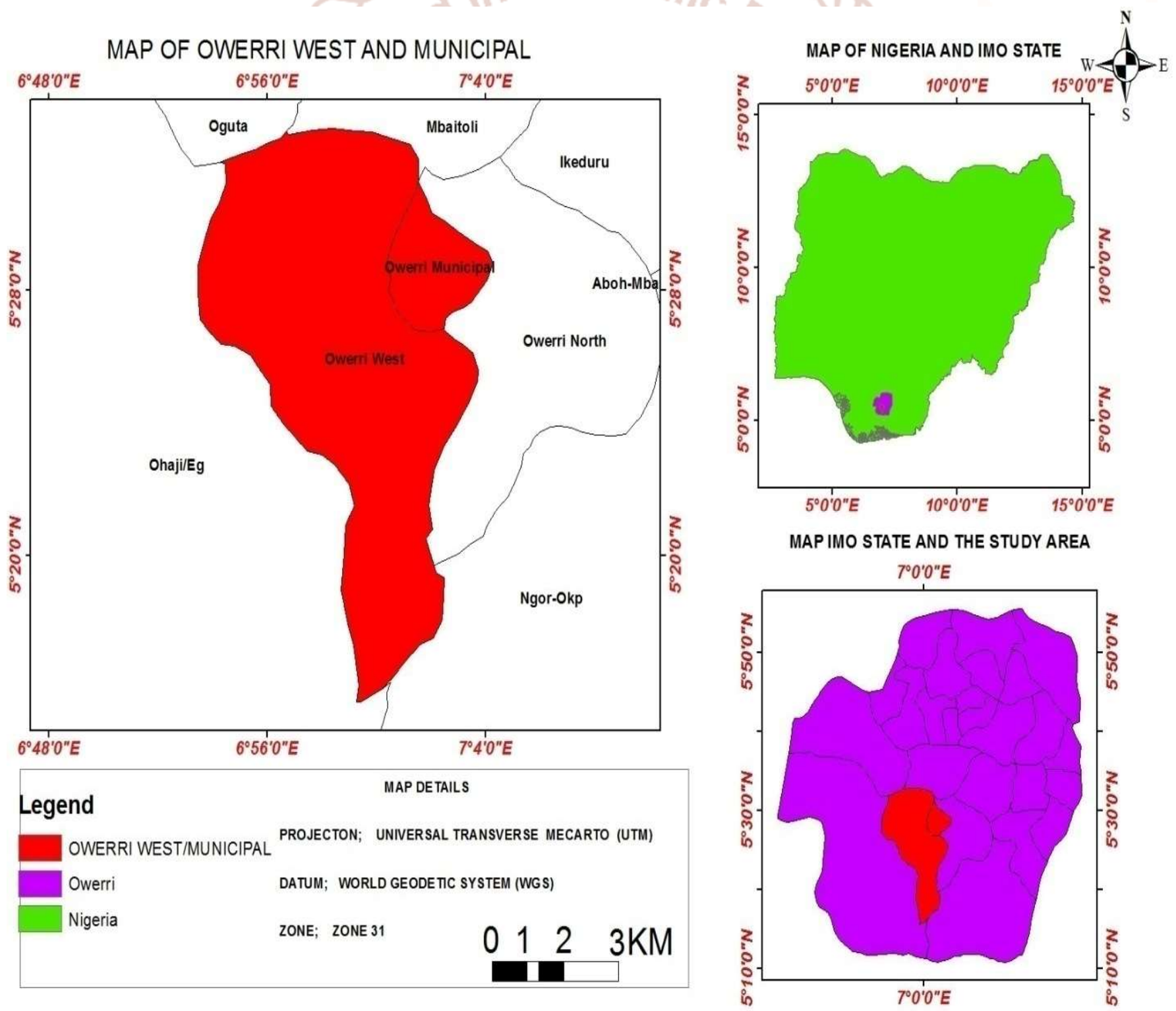

Figure 1: Map of Imo state showing the study area 


\section{METHODOLOGY}

In situ measurement of concentrations of $\mathrm{CO}, \mathrm{NO}_{2}$ and $\mathrm{SO}_{2}$ which characterize the major pollutant gases of vehicular emission was carefully carried out.Five sampling stations(Table 4) were selected and the criteria for their choice was based on traffic intensity, peak period of time and road network.

Table 4: Location of Areas/Sampling points.

\begin{tabular}{|c|c|c|c|}
\hline $\mathbf{S} / \mathbf{N}$ & $\begin{array}{l}\text { Sample } \\
\text { Locations }\end{array}$ & $\begin{array}{l}\text { Sample } \\
\text { points }\end{array}$ & Description \\
\hline \multirow[b]{2}{*}{1} & \multirow{2}{*}{$\begin{array}{l}\text { SPL1 - Fire } \\
\text { Service } \\
\text { Roundabout }\end{array}$} & $\mathrm{P} 1$ & Along Egbu Road \\
\hline & & $\mathrm{P} 2$ & $\begin{array}{l}\text { Fire Service by } \\
\text { Wetheral }\end{array}$ \\
\hline \multirow[t]{2}{*}{2} & \multirow[t]{2}{*}{$\begin{array}{l}\text { SPL2 - MCC } \\
\text { Junction }\end{array}$} & P3 & $\begin{array}{l}\text { MCC Road by } \\
\text { Wetheral }\end{array}$ \\
\hline & & $\mathrm{P} 4$ & Along MCC Road \\
\hline \multirow[b]{2}{*}{3} & \multirow{2}{*}{$\begin{array}{l}\text { SPL3 - } \\
\text { Okigwe } \\
\text { Junction }\end{array}$} & P5 & Along Bank Road \\
\hline & & P6 & $\begin{array}{l}\text { Okigwe by } \\
\text { Wetheral }\end{array}$ \\
\hline \multirow{3}{*}{4} & SPL4 - & D7 & Control By PHC \\
\hline & Control & & Road \\
\hline & Roundabout & & $\begin{array}{l}\text { Control By } \\
\text { Onitsha Road }\end{array}$ \\
\hline 5 & $\begin{array}{l}\text { SPL0 - } \\
\text { Control }\end{array}$ & $\mathrm{P} 0$ & $\begin{array}{l}\text { FUTO - ASUU } \\
\text { Secretariat rend }\end{array}$ \\
\hline
\end{tabular}

\section{Methods of Measurement}

Suspended Particulate Matter (SPM) was measured using an Aerocet 531 particle mass monitor to measure respirable and total suspended particle. Measurements were done by holding the sensor to a height of about two meters in the direction of the prevailing wind and readings recorded at point of stability. The following noxious gases; Carbon Monoxide (CO), Sulphur oxides $\left(\mathrm{SO}_{\mathrm{x}}\right)$, Nitrogen Dioxides $\left(\mathrm{NO}_{2}\right)$, Hydrogen Sulphide $\left(\mathrm{H}_{2} \mathrm{~S}\right)$, Methane $\left(\mathrm{CH}_{4}\right)$, Ammonia $\left(\mathrm{NH}_{3}\right)$ and Volatile Organic Compounds (VOCs) were measured using Standard methods as described below.

A $B W$ Multi gas Monitor with range of detection $0.1-$ $100 \mathrm{ppm}$ equipped with photochemical sensor was used for the measurement of $\mathrm{CO}$. Measurements were done by holding the sensor to a breathing height of about 1.5 meters in the direction of the prevailing wind, while readings was recorded at stability when the monitor had warmed up sensors and air pumped into the sensor. An Aeroqual Environmental gas Monitor equipped with infrared sensor was used for the measurement of $\mathrm{SO}_{2}$. The technique operates on the principle of dual wavelength IR Absorption, having detection range between $0.01-1000 \mathrm{mg} / \mathrm{m}^{3}$ with alarm set at 5.00 and $20.00 \mathrm{mg} / \mathrm{m}^{3}$. Measurements were done by holding the sensor to a breathing height of about 1.5 meters in the direction of the prevailing wind and reading was recorded when the monitor had warmed up (3minutes) to burn off contaminants on the sensor and air sucked into the sensor. An Aeroqual Environmental gas Monitor equipped with infrared sensor was used for the measurement of $\mathrm{NO}_{2}$. The technique operates on the principle of dual wavelength IR Absorption, having range of detection between $0.001-1 \mathrm{mg} / \mathrm{m}^{3}$ with alarm set at 0.002 and $1.000 \mathrm{mg} / \mathrm{m}^{3}$. Measurements were done by holding the sensor to a breathing height of about 1.5 meters in the direction of the prevailing wind. Reading was recorded when the monitor had warmed up (3minutes) to burn off contaminants on the sensor and air sucked into the sensor. A BW Multi gas Monitor equipped with photochemical sensor was used for the measurement of $\mathrm{H}_{2} \mathrm{~S}$. Measurements were done by holding the sensor to a breathing height of about 1.5 meters in the direction of the prevailing wind, with readings recorded when the monitor had warmed up. A BW Multi gas Monitor equipped with photochemical sensor was used for the measurement $\mathrm{ofNH}_{3}$. The range of detection is between 1.0- $25 \mathrm{ppm}$ with alarm set at 2 and $10 \mathrm{ppm}$. Measurements were done by holding the sensor to a breathing height of about 1.5 meters in the direction of the prevailing wind and readings was recorded when the monitor had warmed up sensors. Aeroqual Environmental gas Monitor equipped with infrared sensor was used for the measurement of VOCs. The Equipment operates on the principle of dual wavelength IR Absorption, The range of detection is between $0.1-1000 \mathrm{mg} / \mathrm{m}^{3}$ with alarm set at 0.20 and $50.00 \mathrm{mg} / \mathrm{m}^{3}$. Measurements were done by holding the sensor to a breathing height of about 1.5 meters in the direction of the prevailing wind, and readings were recorded when the monitor had warmed up (3minutes) to burn off contaminants on the sensor and air sucked into the sensor.

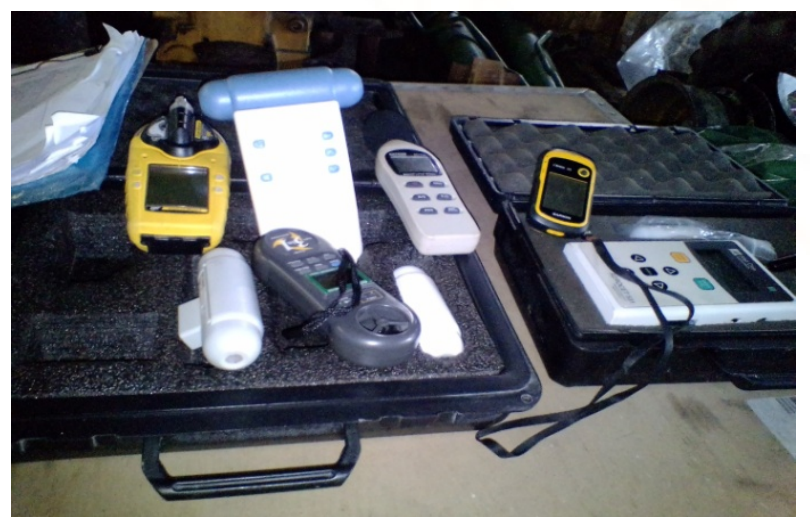

Figure 2: Calibrated Equipment Used for the Study. 
International Journal of Trend in Scientific Research and Development (IJTSRD) ISSN: 2456-6470

\section{RESULTS AND DISCUSSION}

TABLE 4: THE MEAN VALUES OF THE POLLUTANTS

\begin{tabular}{|c|c|c|c|c|c|c|c|c|c|c|c|}
\hline STATION & TIMIE & PM7 & PM10 & TSP & NO2 & SO2 & VOC & H2S & CO & NH3 & CH4 \\
\hline CONTROL JUNCT & $\mathrm{A}$ & 0.075 & 0.170 & 0.317 & 0.107 & 0.140 & 0.200 & 0.000 & 4.500 & 5.000 & 0.500 \\
\hline CONTROL JUNCT & $\mathrm{M}$ & 0.210 & 0.313 & 0.423 & 0.107 & 0.130 & 0.200 & 0.000 & 4.000 & 5.500 & 0.500 \\
\hline FUTO & $\mathrm{M}$ & 0.016 & 0.018 & 0.019 & 0.055 & 0.010 & 2.000 & 1.000 & 1.000 & 1.000 & 1.000 \\
\hline MCC & $\mathrm{A}$ & 0.084 & 0.064 & 0.116 & 0.122 & 0.070 & 0.600 & 0.500 & 10.500 & 4.500 & 0.500 \\
\hline MCC & $\mathrm{M}$ & 0.079 & 0.099 & 0.121 & 0.117 & 0.065 & 0.400 & 0.500 & 11.500 & 6.000 & 0.500 \\
\hline OKIGWE ROAD & $\mathrm{A}$ & 0.101 & 0.189 & 0.308 & 0.108 & 0.000 & 0.150 & 0.500 & 7.500 & 3.500 & 0.000 \\
\hline OKIGWE ROAD & $\mathrm{M}$ & 0.134 & 0.217 & 0.318 & 0.156 & 0.000 & 0.150 & 0.500 & 12.500 & 3.500 & 0.000 \\
\hline WETHERAL & $\mathrm{A}$ & 0.092 & 0.125 & 0.208 & 0.098 & 0.420 & 0.550 & 0.000 & 8.500 & 3.000 & 0.000 \\
\hline WETHERAL & $\mathrm{M}$ & 0.048 & 0.061 & 0.115 & 0.096 & 0.480 & 0.750 & 0.000 & 12.500 & 4.000 & 0.000 \\
\hline
\end{tabular}

\section{TIME DATA ANALYSIS OF THE SAMPLED STATIONS}

\section{TIME DATA OF OKIGWE ROAD-FUTO}

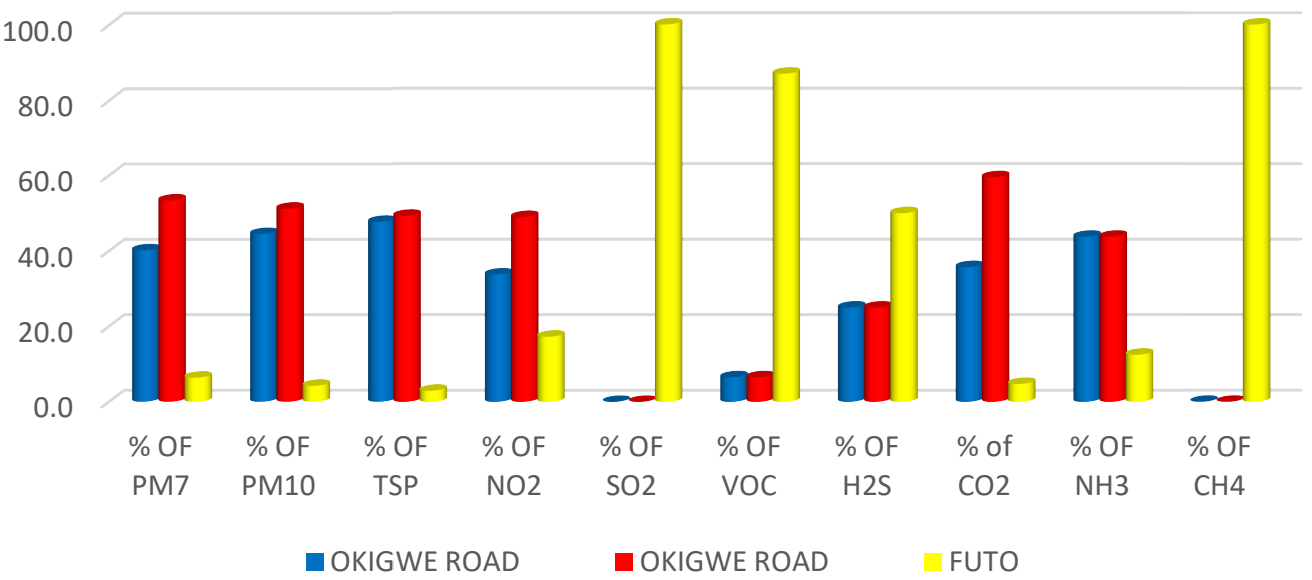

Figure 3:Time Data analysis of Okigwe road - FUTO

TIME DATA WETHERAL -FUTO
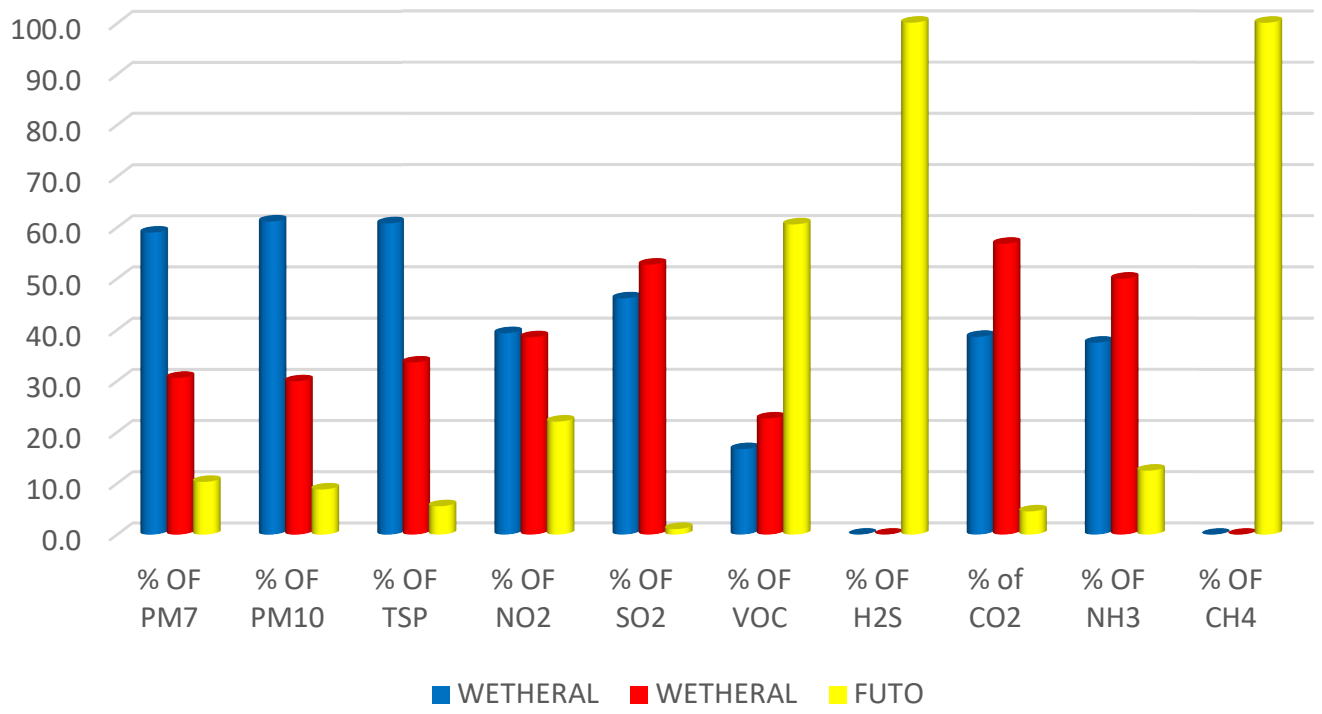

Figure 4:Time Data analysis of Wetheral Road - FUTO 
The analysis was done at the time the pollutants were sampled with respect to morning and afternoon hours. The result shows that the concentration of these pollutants in this region is specifically higher in the morning hours than in the afternoon hours, for particulate matter, but other pollutants showed higher values in the afternoon and along Wetheral due to the increase of gas emission from cars of people driving to their places of works. Particulate matter is primarily produced by mechanical processes such as construction activities, which produces road dust transported by wind(Mishra,2008), whereas the latter originates primarily from combustion sources.

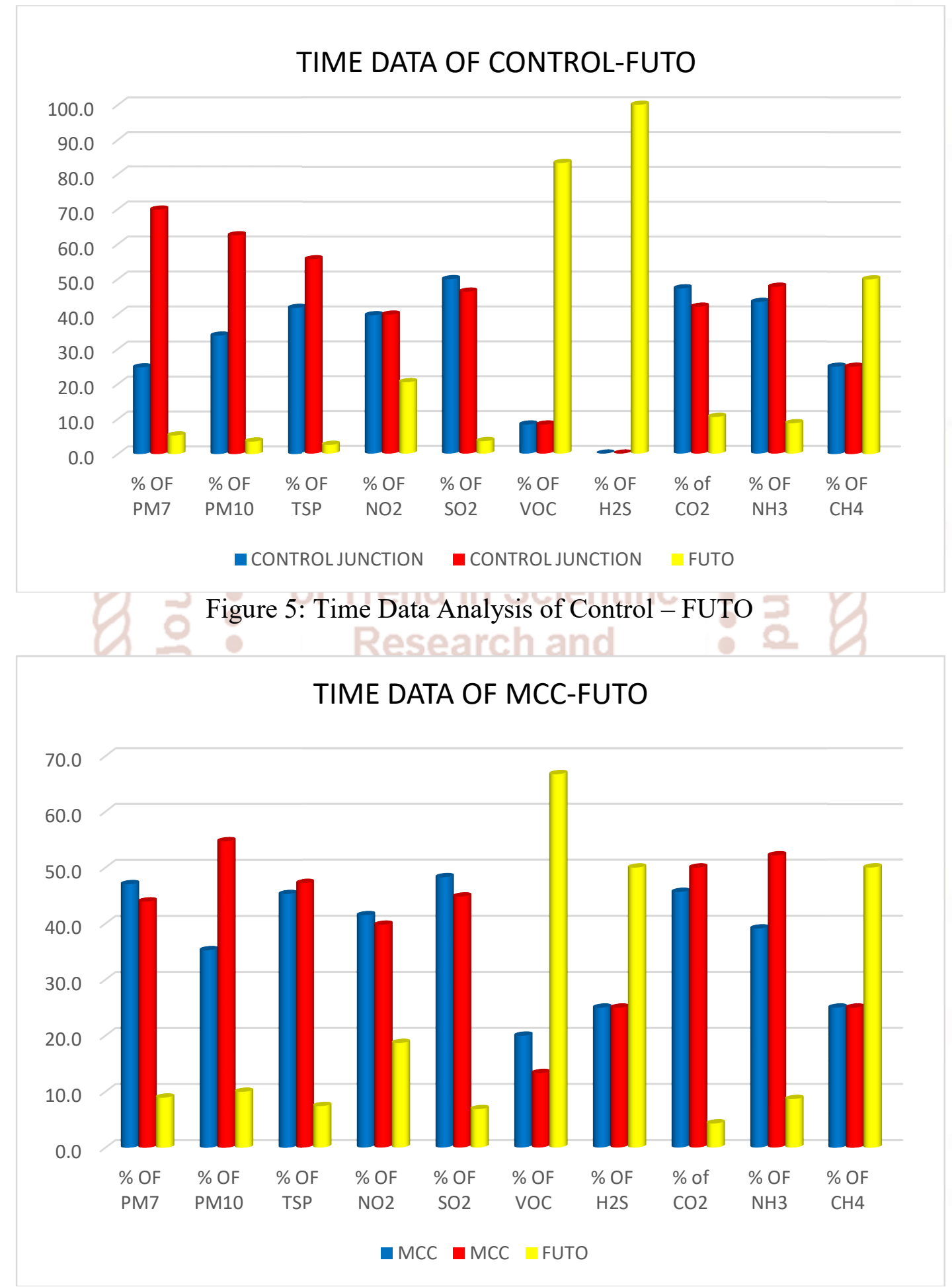

Figure 6: Time Data Analysis of MCC - FUTO.

The results further showed a comparison of all the sites with respect to the NAAQ standard. The results of the study showed that all the sites exceeded the average concentration level of $\mathrm{NO}_{2}$ set bythe standard except in FUTO which was within the range. The reason for the high concentration of $\mathrm{NO}_{2}$ in these sites 
is as a result of high temperature combustion in automobile engines. The $\mathrm{SO}_{2}$ level in all the sites exceeded the 24 hour averaging time of $0.02 \mathrm{ppm}$ in the morning and afternoon except for FUTO and Okigwe Road which fell below or has no $\mathrm{SO}_{2}$ concentration according to the NAAQS standard. This is totally different in the case of Wetheral which had the highest concentration of all the sites both in the morning and afternoon times followed by Control Junction and MCC. Similarly, a survey conducted by Abam and Unachukwu (2009) in Calabar revealed a rise in the concentration of $\mathrm{NO}_{2}$ and $\mathrm{SO}_{2}$ especially at highly congested traffic points. When assessed using Air Quality Index, the concentration of $\mathrm{SO}_{2}$ ranged between $0.04 \mathrm{ppm}$ to $0.15 \mathrm{ppm}$ (poor to very poor). Similarly, $\mathrm{NO}_{2}$ ranged from poor to very poor at concentrations of between $0.02 \mathrm{ppm}-0.09 \mathrm{ppm}$. The $\mathrm{CO}$ level in all the sites exceeds the 1 hour averaging time of 10ppm in the morning except for Control junction and FUTO, but the CO level in all the site is below the 1 hour averaging time of $10 \mathrm{ppm}$ excepts for MCC which is above the standard. The high concentration of $\mathrm{CO}$ in the affected areas is as a result of incomplete combustion of fossil fuel in automobile engines which occurs all through the day. The same is observed for the 8 hours averaging time of $20 \mathrm{ppm}$ for which all parameters were below the WHO standard limit. A similar work by Ndoke and Jimoh (2000) at Minna, a city in Nigeria showed that the maximum value for $\mathrm{CO}$ emission obtained was $15 \mathrm{ppm}$ which is also still lower than the base line of 48ppm stipulated by WHO and 20ppm stipulated by Federal Environmental Protection Agency of Nigeria (FEPA, 1991). The implication of this is that in as much as people subsist daily in these areas to carry out their business activities, they are constantly exposed to these concentrations of pollutants which are released at ground level (i.e. human breathing level) with their attendant health implication (Nwachukwu \& Chukwuocha,2012). An individual's exposure to a CO level as recorded in the sites (above $20 \mathrm{ppm}$ ) is capable of causing headache, dizziness and exertion. It may even be severe in individuals with health conditions such as asthma. The average distribution and trend analysis of the pollutants (Figs.7, 8) shows the variations as a result of location and time of sampling.

\section{Average distribution of the pollutants}

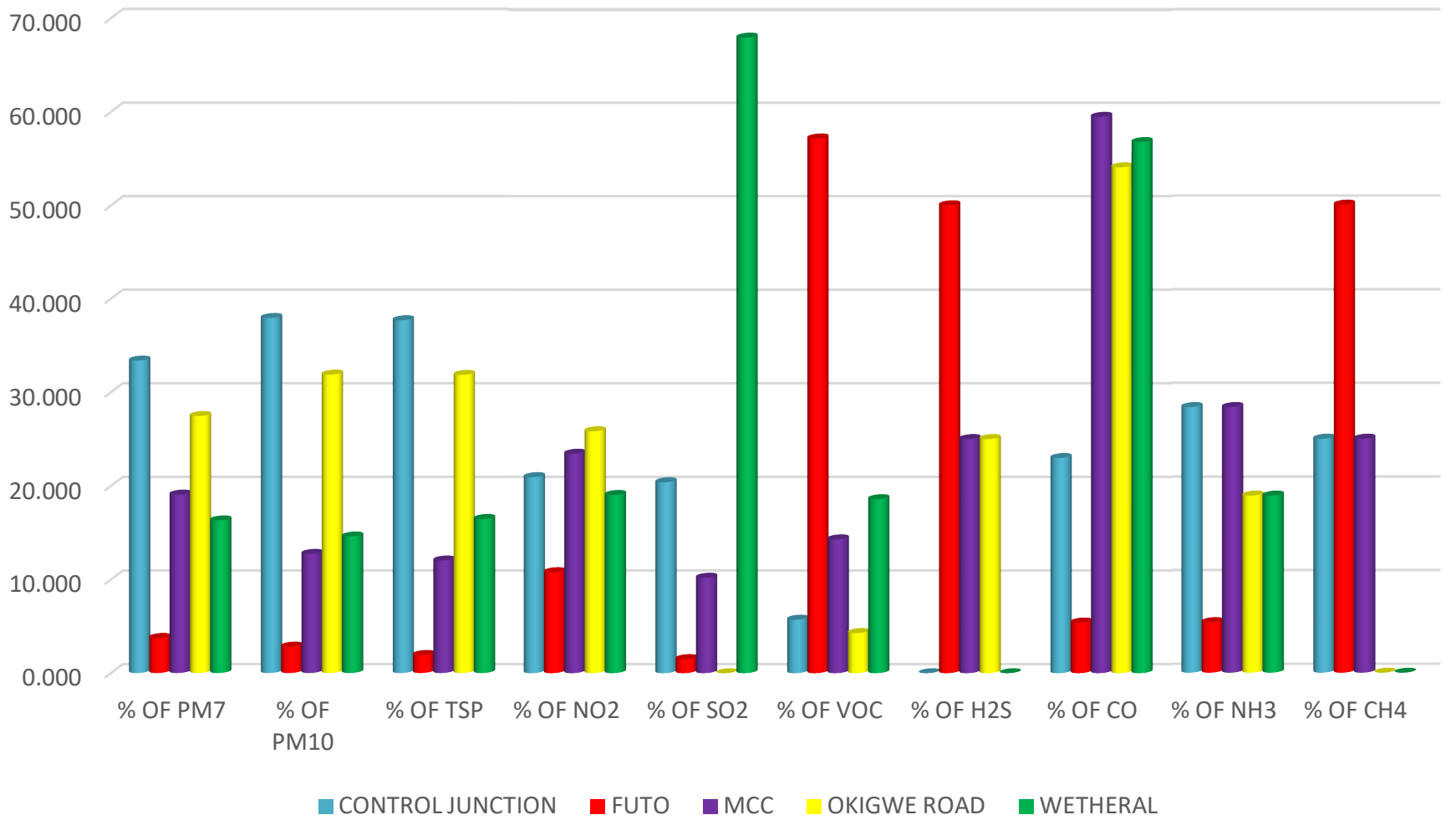

Figure 7: Average distribution of pollutants 


\section{Trend analysis of pollutants}

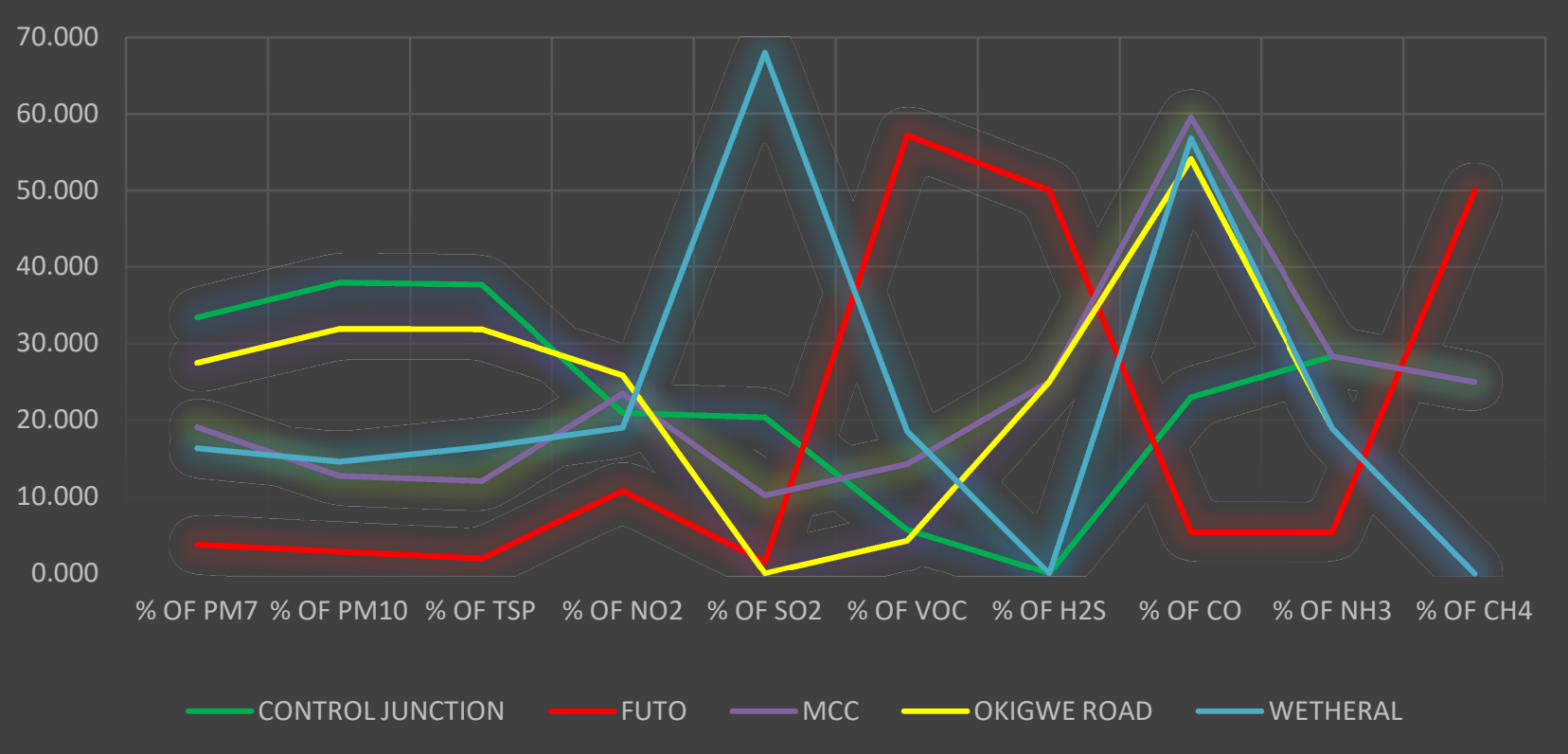

Figure 8: Trend analysis of pollutants.

\section{CONCLUSIONS}

From the reported study, air quality in Owerri Municipal, varied in space and time. Though areas around the Control Junction and the Wetheral Junction experienced high traffic congestion and low air quality in most times of the day, the study from the monitoring of the sites indicated that the average distribution of the pollutants varied with respect to the location. Control Junction had the highest concentration of $\mathrm{PM}_{7}, \mathrm{PM}_{10}$ and TSP, as a result of mechanical and construction activities being carried out in this area. Okigwe Road had the highest concentration of $\mathrm{NO}_{2}$, Wetheral Junction had the highest concentration of $\mathrm{SO}_{2}$, while FUTO had the highest concentration of $\mathrm{VOC}, \mathrm{CH}_{4}$ and $\mathrm{H}_{2} \mathrm{~S}$; as a result indiscriminate dumping of waste around the school environment. MCC has the highest concentration of $\mathrm{CO}$ followed closely by Wetheral and Okigwe. MCC and Control has the same concentration level of $\mathrm{NH}_{3}$. When compared with National Ambient Air Quality Standards, the pollutants exceeded the concentration limits required for healthy air quality. However, because some residences and structural facilities were situated close to the study locations, background concentrations in those areas were high when compared to other background locations; this is because the dispersion of these pollutants was at a lower rate.

\section{RECOMMENDATIONS}

In order to mitigate the problems/challenges posed by vehicular traffic emissions in Owerri, emissions from vehicular traffic can be mitigated if emission standards are set and enforced by the relevant agents of government. Such measure will require all vehicles to pass an emission test to be deemed fit to ply the road. This will encourage vehicle owners to carry out regular maintenance checks on their vehicles. Other measures include, improvement in public transport operation, funding of research by government, land use planning, promoting public awareness and education and vehicle age

\section{REFERENCES}

1. Abam, F. I. and Nwachukwu, G. O. (2009). Vehicular emission and air quality standards in Nigeria. European Journal of Scientific Research 34(4):550- 560.

2. Alias, M., Hamzah, Z. and Kenn, L. S. (2007). PM10 and total suspended particulates (TSP) measurement in various power stations. Malaysian Journal of Analytical Sciences, 11(1):255 - 261.

3. Ahrens, C. D. (2003). Meteorology Today - An Introduction to Weather, Climate and the Environment, 7th edition, Thomson Brooks/Cole, pp.20-24. 
4. Asheshi, O. O. (2012). Measurement of Traffic Emission in Lafia Metropolis. Journal of Science and Multidisciplinary Research. 4:34-44

5. Brunekreef, B. (2005). Out of Africa, Occupation and Environmental Medicine.62:351- 352. BMJ publishing group.

6. Colvile, R. N., Hutchinson, E. J., Mindell, J. S. \& Warren, R. F. (2001) The transport sector as a source of pollution, Atmospheric environment, vol. 35 , pp. $1537-1565$

7. David, R. L. and Frederikse, H. P. R. (1997). Handbook of Chemistry and Physics.28th Edition.

8. Dickey, J. H. (2000) Selected topics related to occupational exposures - part vii: air pollution: overview of sources and health, DM Disease Mouth, vol. 46, No. 9, pp.556-589.

9. Faboye, O. O. (1997). Industrial pollution and waste management. PP 26-35 in Akinjide Osuntogun (ed.). Dimensions of Environmental Problems in Nigeria, Ibadan Davidson press limited, Nigeria.

10. Fenger, J. (1999). Urban Air Quality, Atmospheric Environment, Vol. 33, PP. 4877- 4900

11. FEPA (1991). Guidelines and standards for environmental pollution control in Nigeria. Federal Environmental Protection Agency press, LagosFu, L. (2001). Assessment of Vehicle Pollution in China. Journal of the Air and Waste Management: 51(5):658 - 668 .

12. Garba, A. G. and Garba, P. K. (2001). Market Failure and Air Pollution in Nigeria: A theoretical investigation of two cases, selected papers, Annual Conference of Nigerian Economic Society, held in Port-Harcourt.

13. Goyal, S. (2006). Understanding urban vehicular pollution problem vis-à-vis ambient air quality. Case study of megacity (Delhi, India). Environmental monitoring and assessment, 119:557-569.

14. Iyoha, M. A. (2009). The environmental effects of oil industry activities on the Nigerian economy: A Theoretical Analysis. Paper presented at the National conference on the Management of
Nigeria"s Petroleum Resources organized by the Department of Economics, Delta State University.

15. Magbabeola N. O (2001). The use of Economic Instruments for Industrial pollution Abatement in Nigeria: Application to the Lagos Lagoon. Selected papers, Annual Conferences of the Nigerian Economic Society held in Port-Harcourt.

16. Mishra, P. C. (2008). Fundamentals or Air and Water Pollution, New Delhi: APH publishers limited. P. 7-17.

17. Ndoke P. N. and Jimoh D.O. (2000). Impact of Traffic Emission on Air Quality in a Developing City of Nigeria. Unpublished paper presented at the Department of Civil Engineering, Federal University of Technology Minna, Nigeria.

18. Nwachukwu, A. N., Chukwuocha, E. O. and Igbudu, O. (2012). A survey on the effects of air pollution on diseases of the people of Rivers State, Nigeria. African Journal of Environmental Science and Technology Vol. 6(10):371-379.

19. Rouphail, N. M., Frey, H. C., Colyar, J. D. and Unal, a (2001). Vehicle emissions and traffic measures: Exploratory analysis of field observation at signalized arterials. Paper presented at the 80th Annual Meeting of the Transportation Research Board.

20. USEPA (2003). Guideline for Reporting Daily Air Quality. Air Quality Index (AQI), EPA454/k-03002, Office of Air Quality Planning and Standards: Research Triangle Park, NC.

21. Utang, P. B., and Peterside, K. S. (2011). Spatiotemporal variations in urban vehicular. Ethiopian Journal of Environmental Studies and Management, 4(2).

22. WHO (2004). Health Aspects of Air Pollution: Results from the WHO project. "Systematic Review of Health Aspects of Air Pollution in Europe".

23. World Bank (1995). Defining Environmental Development Strategy for the-Niger Delta. DRAFT REPORT on Niger Delta Wetlands Volume II. World Bank, Washington DC. May 25 th. 